\title{
Experimental Study of Nitrogen Removal Efficiency of Layered Bioretention Under Intermittent or Continuous Operation
}

\author{
Chunbo Jiang ${ }^{1}$, Jiake $\mathrm{Li}^{1 *}$, Huaien $\mathrm{Li}^{1}$, Yajiao $\mathrm{Li}^{2}$ \\ ${ }^{1}$ State Key Laboratory Base of Eco-Hydraulic Engineering in Arid Area, \\ Xi'an University of Technology, Xi'an 710048, China \\ ${ }^{2}$ School of Architecture and Civil Engineering, Xi'an University of Science and Technology, \\ Xi'an 710054 , China
}

Received: 3 November 2016

Accepted: 9 December 2016

\begin{abstract}
The structural configuration of bioretention plays an important role in the consumption and purification of nitrogen pollutants in rainfall runoff. Three layered bioretention tanks - 7\#, 9\#, and 10\#-with artificial packing layers of fly ash mixing sand, blast furnace slag, and planting soil, respectively, were selected for intermittent and continuous operational tests. All load-reduction rates of nitrogen pollutants for intermittent running test exceeded $40 \%$ in three tanks, and tank 7 \# showed $>70 \%$. Moreover, the effluent pollutant concentration of $7 \#$ increased with time, whereas those of $9 \#$ and $10 \#$ fluctuated and then decreased slowly. The correlation model between $\mathrm{TN}$ removal and its influencing factors was established using the partial least regression method. Modeling analysis suggested that the filler type was the most important factor affecting TN removal. TN removal was positively correlated with packing factor and submerged zone height, while it was negatively correlated with antecedent dry time and influent loading. Soil pollutant original content and texture classification were detected before the continuous running test. The percentages of $\mathrm{NO}_{3}-\mathrm{N}$ and $\mathrm{NH}_{3}-\mathrm{N}$ accumulating in three facilities accounted for a total influent load of approximately $77 \%$ (7\#), 61\% $(9 \#)$, and $43 \%(10 \#)$ when the exhaustion point was reached, demonstrating the relatively poor performance of planting soil.
\end{abstract}

Keywords: nitrogen, bioretention, intermittent running, continuous operation, modeling

\section{Introduction}

Non-point source pollution has increasingly impacted water pollution in cities with the improvement of controlling point-source pollution [1]. Storm-water

*e-mail: xaut_ljk@163.com runoff contains excess nutrients that contribute to the process of eutrophication of surface water, resulting in the degradation of the quality of drinking water and recreational water. Monitoring results of 61 lake (reservoir) nutritional status from the Chinese environmental report of 2015, eutrophication, nutrition, and oligotrophic lakes (reservoirs) were $23 \%, 67 \%$, and 10\%, respectively [2]. As one of the major nutrients in storm runoff, nitrogen mainly comes from lawn fertilizers, fallen leaves, grass clippings, 
fertilized soil, detergents, atmospheric deposition, and precipitation [3]. Pollutants in rainwater accumulate, scour, and are transported before they enter the receiving water [4]. Scouring involves supply (background value) and transmission limits. Nitrogen scouring performed the process of supply limitation, whereas phosphorus performed the transmission limitation. Expressing the flushing of nutrients based on particles (especially nitrogen pollutants scoured), may produce inaccurate results [5]. Therefore, appropriate measures should be taken to reduce the nitrogen load in storm-water runoff, which is discharged into the receiving water.

Total nitrogen (TN) includes particulate organic nitrogen $(\mathrm{PON})$, dissolved organic nitrogen (DON), ammonia $\left(\mathrm{NH}_{3}-\mathrm{N}\right)$, nitrite $\left(\mathrm{NO}_{2}-\mathrm{N}\right)$, and nitrate $\left(\mathrm{NO}_{3}-\mathrm{N}\right)$ [6]. Dissolved pollutants (DON, $\mathrm{NH}_{3}-\mathrm{N}, \mathrm{NO}_{2}{ }^{-} \mathrm{N}$, and $\mathrm{NO}_{3}{ }^{-} \mathrm{N}$ ) are more mobile, bioavailable, and are captured via different mechanisms than particles [7]. A bioretention system utilizes decentralized landscape, hydrology and hydraulic design, replacement or reinforcement of soils, plants to control storm runoff, and non-point source pollution. The media intercept pollutants through sedimentation and adsorption when rain runs into the bioretention system and then is transformed through conversion between pollutants and microbial degradation. Li et al. [8] found that the total nitrogen (TN) load cut rate (inflow-outflow TN load through the perforated drain pipe/inflow TN load) is $41 \%$ when the inflow TN load is $14.0 \mathrm{~kg} /$ (ha year), and the percentage caused by leakage loss accounted for $31.5 \%$, whereas that retained in the bioretention facilities accounted for 9.7\%. Meanwhile, $5.3 \mathrm{~kg}$ /ha-year of the captured PON (6.7 kg/ha-year) appears to undergo mineralization, ammonification, and nitrification to $\mathrm{DON}$ and $\mathrm{NO}_{3}-\mathrm{N}$ between storm events. $\mathrm{NH}_{3}-\mathrm{N}$ is a positive ion, which can be removed by adsorption to a negatively charged media when rain runs into the system first. The removal of $\mathrm{NH}_{3}-\mathrm{N}$ by bioretention soil media (BSM) primarily relies on the nitrification of $\mathrm{NH}_{3}-\mathrm{N}$ to $\mathrm{NO}_{3}-\mathrm{N}$ by nitrite and nitrate bacteria, then $\mathrm{NO}_{3}{ }^{-}$transforms to $\mathrm{NO} / \mathrm{N}_{2} \mathrm{O} / \mathrm{N}_{2}$ under anoxic conditions through denitrification.
A variety of internal and external conditions affect the bioretention operation results [9-10]. Bratieres et al. [11] tested plant species, filter media, filter depth, filter area, and pollutant inflow concentration for optimal design. The "optimal specifications" can remove up to $70 \%$ nitrogen and over $95 \%$ suspended solids consistently. The optimally designed biofilter is at least $2 \%$ of its catchment area and possesses a sandy loam filter planted with C. appressa or M. Ericifolia. Enhanced nitrogen removal has been observed when the bioretention system includes a submerged zone height, carbon source, and artificial packing [12-14]. A triple-layer design would be designed to ensure nitrogen removal. A top layer of organicamended sand could capture particle organic matter and promote plant growth, and the artificial packing middle layer could help adsorb pollutants, including nitrogen, and an internal storage zone with e-donor could promote denitrification. On the whole, the key problem for nitrogen removal of bioretention design is BSM composition and structural configuration.

This study analyzed the concentration of nitrogen pollutants under intermittent and continuous operation through a simulated rainfall test. We explored the discharge of changing pollutant concentrations for three constructed bioretention devices with different media-layering characteristics. Moreover, the nitrogen removal effect was evaluated by analyzing the quantity of accumulation, leakage, and exhaustion for the bioretention facility under continuous operation, which is dominated by fast adsorption. Additionally, the main influencing factors for bioretention operation were identified, and we established a correlation model with nitrogen removal.

\section{Materials and Methods}

\section{Device Setup}

Ten bioretention tanks from $1 \#$ to $10 \#$ were designed and constructed at the outdoor test ground of Xi'an University of Technology in 2013, and each tank had different a)

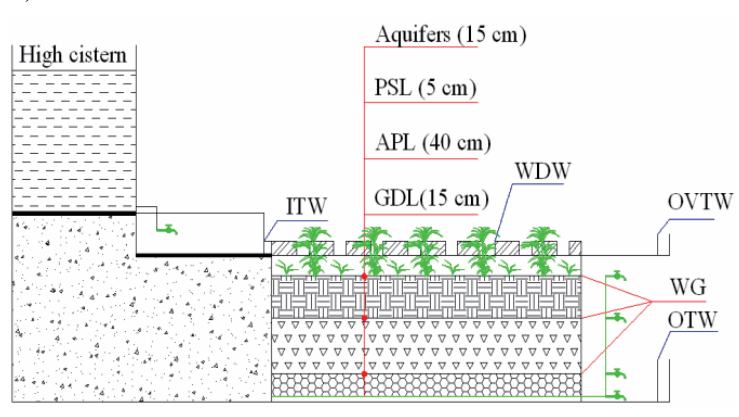

b)

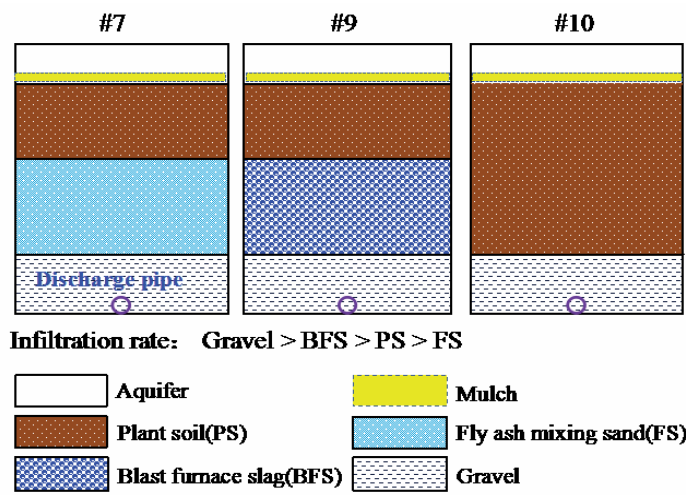

Fig. 1. Cross-section of bio-retention pilot plant. Construction of test tank includes an aquifer, mulch, planting soil layer (PSL), artificial packing layer (APL), and gravel drainage layer (GDL) from top to bottom. WDW for water distribution weir, ITW for inflow triangle weir, OTW for outflow triangle weir, OVTW for over triangle weir, and WG for waterproof geotextile. 


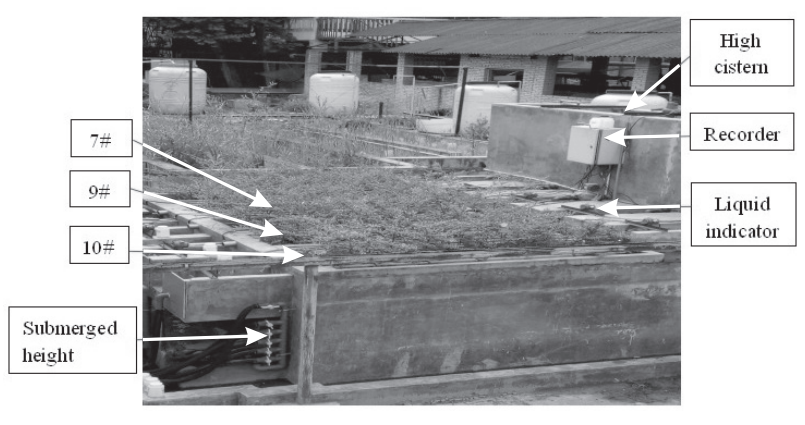

Fig. 2. Pictures of bioretention pilot plant.

structural configurations. Bioretention tanks 7\#, 9\#, and $10 \#$ were selected for the experiments on intermittent running and continuous operation. The dimensions of each groove were $2.0 \mathrm{~m} \times 0.5 \mathrm{~m} \times 1.05 \mathrm{~m}$ (length $\times$ width $\times$ depth). The structural configuration was aquifer layer, planting soil, artificial fillers, and gravel drainage layer from the top downward. Artificial packing layer of test grooves were fly ash mixing sand (FS, volume ratio 1:1), blast furnace slag (BFS), and plant soil (PS). Ligustrum quihoui Carr and Ophiopogogon japonicas, which are commonly used for greening roads, were planted in the bioretention devices, with a covering layer of Platanus orientalis Linn leaf. An XTHJ recorder (Teng Hui temperature control instrument and meter plant in Yuyao, Zhejiang Province) was installed in front of a $30^{\circ}$ triangular weir to observe the inflow, outflow, and overflow current capacities. The cross-section of a bioretention plant is shown in Fig. 1, and a picture of the retention plant is shown in Fig. 2.

\section{Monitoring and Analysis Methodology}

The ratio of the surface area to the catchment area of typical bioretention facilities is $1 / 20-1 / 10$ [15]. This ratio was set to $17: 1$ in this study, and rainfall was calculated by $2 \mathrm{~h}$ rainfall volume in $0.5 \mathrm{a}$ (year), 2 a, and $5 \mathrm{a}$, based on the Xi'an rainstorm intensity formula [16]. High and low pollutant concentrations were designed from actual monitoring data in Xi'an city according to the studies of Yuan [17] and Dong [18]. The concentrations of the test water are shown in Table 1. This test required the simulation of the complete process of rains from the start to the end, including "grow-peak-fall." Cen et al. [19] found a single-peak rain pattern mainly in a short period of rains, and most of the peak flow appeared in the front and at the center using extensive modeling and comparison. The effect was better observed when the peak flow or storage volume was calculated using the Chicago- pattern (also known as kiefer and Chu rain pattern). This process could meet the general requirements for accuracy, and the strong process was relatively easy to determine with a wide range of applications both locally and abroad. This test was conducted in accordance with the Chicagopattern, and the factor of peak flow was 0.3.

The parameters for the water quality analysis were temperature, $\mathrm{pH}$, electrical conductivity, dissolved oxygen (DO), TN, total dissolved nitrogen (TDN), $\mathrm{NO}_{3}-\mathrm{N}, \mathrm{NH}_{3}-\mathrm{N}$, and chemical oxygen demand (COD). Water temperature, $\mathrm{pH}$, conductivity, and $\mathrm{DO}$ were used in the instrumental measurement using a HACH HQ40d two-circuit input multi-parameter numerical analysis. The water sample was filtered with a $0.45 \mu \mathrm{m}$ filterable membrane, and the original water sample was oxidized with potassium persulfate. UV spectrophotometry was performed to determine TDN and DN separately. $\mathrm{NO}_{3}-\mathrm{N}$ was determined by employing the phenol disulfonic acid spectrophotometric method. $\mathrm{NH}_{3}-\mathrm{N}$ was analyzed by adopting Nessler's reagent colorimetric method. COD was examined using HACH DRB200 digestion and UV spectrophotometry.

A single-field rainfall event mean concentration (EMC) is the quotient of the total pollutant and the total runoff volume in one rainfall event. This parameter was used to compare quite different rainfall events based on pollutant quantity. However, the change in the actual rainfall process concentration was separately identified. This process enabled the increase in the amount of separate points as far as possible to calculate the pollutant average concentration in a single rainfall event because pollutant concentration cannot correspond with current capacity, as shown by Equation (1), and concentration removal and load removal as a calculation shown by Equations (2) and (3):

$$
\begin{gathered}
E M C=M / V=\int_{0}^{t_{d}} Q_{(t)} C_{(t)} d t / \int_{0}^{t_{d}} Q_{(t)} d t \approx \sum C_{i} Q_{i} \Delta t_{i} / \sum Q_{i} \Delta t_{i} \\
R_{c}=\left(E M C_{\text {in }}-E M C_{\text {out }}\right) / E M C_{\text {in }} \\
R_{L}=\left(M_{\text {in }}-M_{\text {out }}\right) / M_{\text {in }} \times 100 \%
\end{gathered}
$$

...where $R_{c}$ is the pollutant concentration removal rate, $R_{L}$ is load removal rate, $M_{\text {in/out }}$ is inflow/outflow pollutant load, $E M C_{\text {in/out }}$ is the mean concentration of inflow/outflow pollutant, $c(t)$ is the mass concentration of pollutants over time, and $Q(t)$ is flow of unit time.

Table 1. Water concentration and required reagent $(\mathrm{mg} / \mathrm{L})$.

\begin{tabular}{|c|c|c|c|c|c|c|c|}
\hline Concentration & $\mathrm{COD}$ & $\mathrm{NO}_{3}-\mathrm{N}$ & $\mathrm{NH}_{3}-\mathrm{N}$ & $\mathrm{TP}$ & $\mathrm{Cu}$ & $\mathrm{Zn}$ & $\mathrm{Cd}$ \\
\hline High & 600 & 14 & 6 & 2.5 & 1.0 & 1.5 & 0.05 \\
\hline Medium & 300 & 8 & 3 & 1.0 & 0.5 & 0.8 & 0.03 \\
\hline
\end{tabular}


Table 2. Scheme of the intermittent operational test.

\begin{tabular}{|c|c|c|c|c|}
\hline Test number & Pollutant concentrations & Submerged depth $(\mathrm{mm})$ & Antecedent dry time (day) & Inflow volume (L) \\
\hline $\begin{array}{c}\text { Clear water experiment } \\
\text { Test 1 }\end{array}$ & 0 & 0 & 7 & 573.85 \\
\hline Test 2 & Medium & 0 & 7 & 573.85 \\
\hline Test 3 & Medium & 150 & 7 & 573.85 \\
\hline Test 4 & Medium & 0 & 15 & 573.85 \\
\hline Test 5 & Medium & 0 & 7 & 573.85 \\
\hline Test 6 & Medium & 0 & 3 & 573.85 \\
\hline Test 7 & Medium & 0 & 7 & 573.85 \\
\hline Test 8 & Medium & 0 & 7 & 427.16 \\
\hline Test 9 & Medium & 0 & 7 & 573.85 \\
\hline
\end{tabular}

Experimental Scheme

Clear water was used to run the bed before the test. The routine test (including tests 1,3,5, and 8) involved medium pollutant concentration. Water volume was calculated under the 5 a return period, seven days antecedent dry time, and non-internal submerged zone. Test 1 was the preliminary test. Test 2 established the submerged zone height of $150 \mathrm{~mm}$. Antecedent dry time for tests 4 and 6 were 15 and three days, respectively. Water volume of test 7 was under the 2 a return period. Test 9 had higher water concentration. The scheme of intermittent running tests is shown in Table 2.

Adsorption capacity was likely reduced in a few hours when the continuous inflow was considered to be constant under medium concentration. This test increased the hydraulic load from low to high step-by-step. This experiment was designed such that three bioretention facilities ran in low inflow volume (0.5a) for $24 \mathrm{~h}$, then ran for $12 \mathrm{~h}$ with medium inflow volume (2a), finally at high inflow volume (5a) for $8 \mathrm{~h}$ with effective volume of $2,700 \mathrm{~L}$ for the high cistern. The drain valve opening and inflow concentration were constant in each return period. Inflow sample was collected every $2 \mathrm{~h}$, whereas the outflow sample was collected after $0.5 \mathrm{~h}$ to determine the concentrations at different times. The media was assumed to be exhausted if continuous $\mathrm{C}_{\text {out }} / \mathrm{C}(1-10 \%) \geq 1\left(\mathrm{C}_{\text {out }}\right.$ is effluent concentration, and $\mathrm{C}$ is influent concentration). The water volume schedule for a continuous run is shown in Table 3.

\section{Results and Discussion}

\section{Determining Soil Textural Classification and Pollutant Background Value}

This test collected the surface soil $(10 \sim 15 \mathrm{~cm})$ for soil textural classification and pollutant original content analysis, according to the Technical Specification for Soil Environmental Monitoring [20]. After natural drying, the plants, stones and other residues were eliminated from soil samples, then these samples were screened through a 2-mm soil sieve after crushing. Soil textural classification was tested through Mastersizer 2000 wet measurement using United States soil size classification standard $($ clay $<0.002 \mathrm{~mm}$, silt $\approx 0.05 \sim 0.002 \mathrm{~mm}$, sand $\approx 2 \sim 0.05 \mathrm{~mm}$ ) for soil texture classification, and then determined soil texture in accordance with United States soil textural triangle.

The results of soil particle analysis indicated that the percentage of clay, silt, and sand of plant soil in this test are $3.49 \%, 90.36 \%$, and $6.15 \%$, respectively. This means that the textural classification of the soil in these three bioretention tanks is silty soil, which is dominated by silt, and clay content is relatively small. Pollutant background value is shown in Table 4, and it demonstrates that surface soil background values of $\mathrm{pH}, \mathrm{TC}, \mathrm{TOC}$, and $\mathrm{TN}$ were similar in the three bioretention facilities.

Table 3. Water volume schedule for continuous operation.

\begin{tabular}{|c|c|c|c|c|}
\hline Test number & Return period (a) & 2 h rainfall (L) & Running time (h) & Total inflow volume (L) \\
\hline Test 01 & 0.5 & 205.23 & 24 & $2,462.76$ \\
\hline Test 02 & 2 & 427.16 & 12 & $2,562.96$ \\
\hline Test 03 & 5 & 573.85 & 8 & $2,295.39$ \\
\hline
\end{tabular}


Table 4. Background value of pollutants in bioretention facilities.

\begin{tabular}{|c|c|c|c|c|c|c|c|}
\hline Number & $\mathrm{pH}$ & $\begin{array}{c}\mathrm{TC} \\
(\%)\end{array}$ & $\begin{array}{c}\mathrm{TOC} \\
(\%)\end{array}$ & $\begin{array}{c}\mathrm{TN} \\
(\mathrm{mg} / \mathrm{kg})\end{array}$ & $\begin{array}{c}\mathrm{NH}_{3}-\mathrm{N} \\
(\mathrm{mg} / \mathrm{kg})\end{array}$ & $\begin{array}{c}\mathrm{NO}_{2}-\mathrm{N} \\
(\mathrm{mg} / \mathrm{kg})\end{array}$ & $\begin{array}{c}\mathrm{NO}_{3}-\mathrm{N} \\
(\mathrm{mg} / \mathrm{kg})\end{array}$ \\
\hline $7 \#$ & 7.33 & 39.35 & 0.49 & 44.83 & 0.19 & 0.17 & 1.45 \\
\hline $9 \#$ & 7.87 & 37.55 & 1.61 & 48.52 & 0.15 & 0.14 & 1.49 \\
\hline $10 \#$ & 7.95 & 43.80 & 1.12 & 49.15 & 0.08 & 0.09 & 1.14 \\
\hline
\end{tabular}

\section{Analysis of the Effects of Influencing Factors}

Nine rainfall events were conducted for the intermittent running test. Inflow pollutant concentrations are constant, and the sample of the inflow was set at 0,60 , and $120 \mathrm{~min}$ after the start of the test. The outflows were sampled once every $15 \mathrm{~min}$, when the discharge pipe was allowed to leak water. The process lines of eight field tests on pollutant concentration, except for the preliminary experiment (Test 1), are shown in Fig. 3.

$\mathrm{NO}_{3}-\mathrm{N}$ and $\mathrm{NH}_{3}-\mathrm{N}$ were considered as target pollutants. Outflow pollutant concentrations of three bioretention ponds with different packing layers showed distinct trends. Outflow pollutant concentration of 7\# (artificial packing layer for FS) gradually increased along with time, whereas those of 9\# (artificial packing layer for BFS) and 10\# (artificial packing layer for PS) fluctuated and then decreased slowly (Fig. 3). The infiltration process in the layered bioretention tank is divided into three forms, which are a high permeability layer over a lower permeability layer, a low permeability layer over a higher permeability layer, and homogeneous infiltration media. Hsieh et al. [21] noted that a greater proportion of ammonium was removed when there was a high permeability layer over a lower permeability layer. The infiltration rate order of media in this test is BFS $>$ PS $>$ FS.
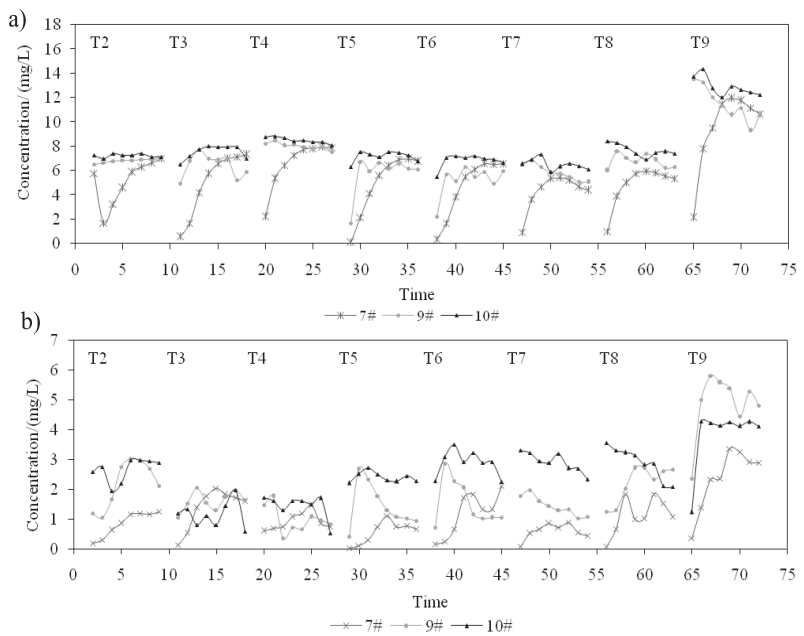

Fig. 3. Process lines of pollutants with different concentrations. a) Nitrate concentration process line; b) Ammonia concentration process line. The test numbers from T2 to T9 in Fig. 3 respectively correspond to those from Test 2 to Test 9 in Table 2 .
The best load-reduction rates of nitrogen pollutants is $7 \#$ (more than 70\%), for which Hsieh et al. obtained a similar conclusion.

O’Neill and Davis [22] combined 5\% water treatment residual (WTR) and 3\% triple-shredded hardwood bark in sand loam in a bioretention tank to improve media adsorption capacity for phosphorus. The concentrations of TP and TDP gradually decreased with inflow time under constant and variable loads, similar to the $9 \#$ and $10 \#$ bioretention tanks, but remarkably different with the $7 \#$ bioretention tank in this test. Changes in the water concentration trend in the current study were affected by three aspects. On the one hand, the surface adsorption capacity of the soil filler achieved a certain recovery with an antecedent dry period of seven days in the general test. The filler surface had faster adsorption points in initial rainfall, while the filler surface fast adsorption area was occupied gradually over time, such that water concentration gradually increased. Columns of municipal compost were irrigated to simulate 6-month, 24-hour rain storms in the Seattle-Tacoma region, and the results showed that compost could serve as a sustained source of leaching of nutrients and metals [23]. Lucke and Nichols [24] also found the negative TN removal for the performance of street-side bioretention basins after 10 years in operation. Water pollutant load was smaller in the early $20 \mathrm{~min}$, when a Chicago rain pattern was chosen as the simulation precipitation test. Then increases and decreases were also observed, indicating the worst media adsorption case when the higher hydraulic load comes. Accumulated pollutants from the system may rush out during rainfall peak flows. Tang et al. [25] results showed that the rain garden had little removal capability for dissolved nitrogen and phosphorus, and they contributed it to the existence of preferential flow in soil. What's more, the difference in packing combinations had different permeabilities, absorption capacities, etc. Thus the outflow concentration wave may be due to preferential flow.

\section{Analytical Results Under Continuous Operation Test}

The exhaustion points of the media were examined through breakthrough curves. Bioretention lifetime was evaluated through cumulative inflow volume and pollutant loads. Breakthrough curves of soil solutes could be divided into continuous and pulse input soil solute breakthrough curves according to the inflow type of trace elements. It could also be divided into saturated and unsaturated solute 
breakthrough curves according to the status of soil water content. Schedules for a continuous operational test are shown in Table 3, and the outflow concentration trends of $\mathrm{NH}_{3}-\mathrm{N}$ and $\mathrm{NO}_{3}-\mathrm{N}$ in three bioretention facilities are shown in Fig. 4.

$\mathrm{NH}_{3}-\mathrm{N}$ in $7 \#$ bioretention was $\mathrm{C}_{\text {out }}>\mathrm{C}(1-10 \%)$ after running for $40 \mathrm{~h}$ and $28 \mathrm{~h}$ for $\mathrm{NO}_{3}-\mathrm{N}$. $\mathrm{NH}_{3}-\mathrm{N}$ effluent concentration for $9 \#$ was $\mathrm{C}_{\text {out }}>\mathrm{C}(1-10 \%)$ after running for $30 \mathrm{~h} . \mathrm{NO}_{3}-\mathrm{N}$, which accumulated in the $9 \#$ bioretention in the early time discharged with the synthetic rainwater, resulted in a higher outflow concentration when initial outflow was sampled. $\mathrm{NH}_{3}-\mathrm{N}$ concentration was $\mathrm{C}_{\text {out }}>\mathrm{C}$ (1-10\%) for $10 \#$ after $26 \mathrm{~h}$. Then, water concentration rose continually, and $\mathrm{C}_{\text {out }}>\mathrm{C}(1+10 \%)$ after $30 \mathrm{~h} . \mathrm{NH}_{3}-\mathrm{N}$ adsorbed in soil particles surface was scoured out when hydraulic load increased, which led to greater outflow than inflow concentration. $\mathrm{NO}_{3}-\mathrm{N}$ concentration fluctuated near $\mathrm{C}(1-10 \%)$ after $14 \mathrm{~h}$, which indicated that $\mathrm{NO}_{3}-\mathrm{N}$ concentration reached adsorption exhaustion for planting soil more quickly than other tanks. The corresponding
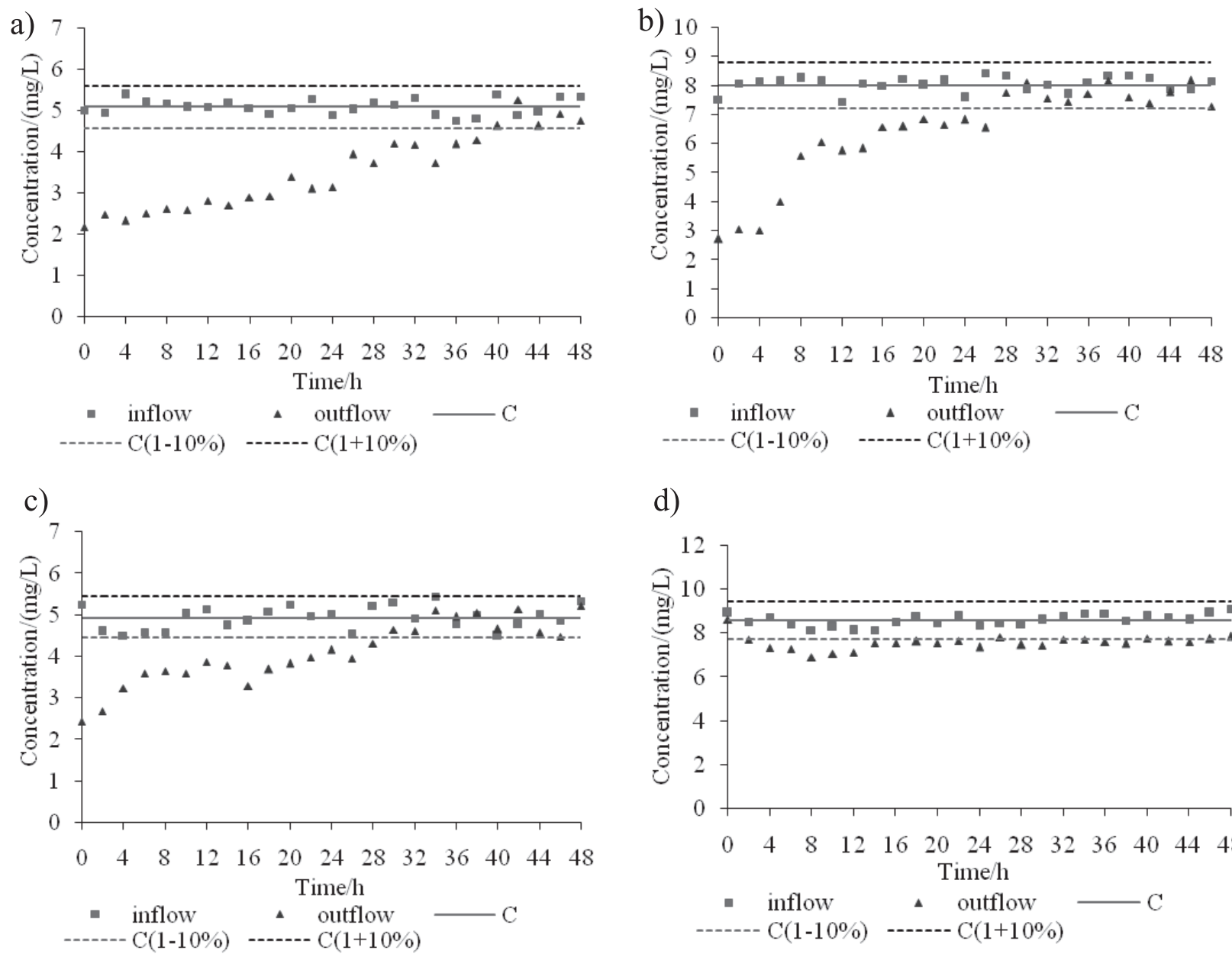

d)
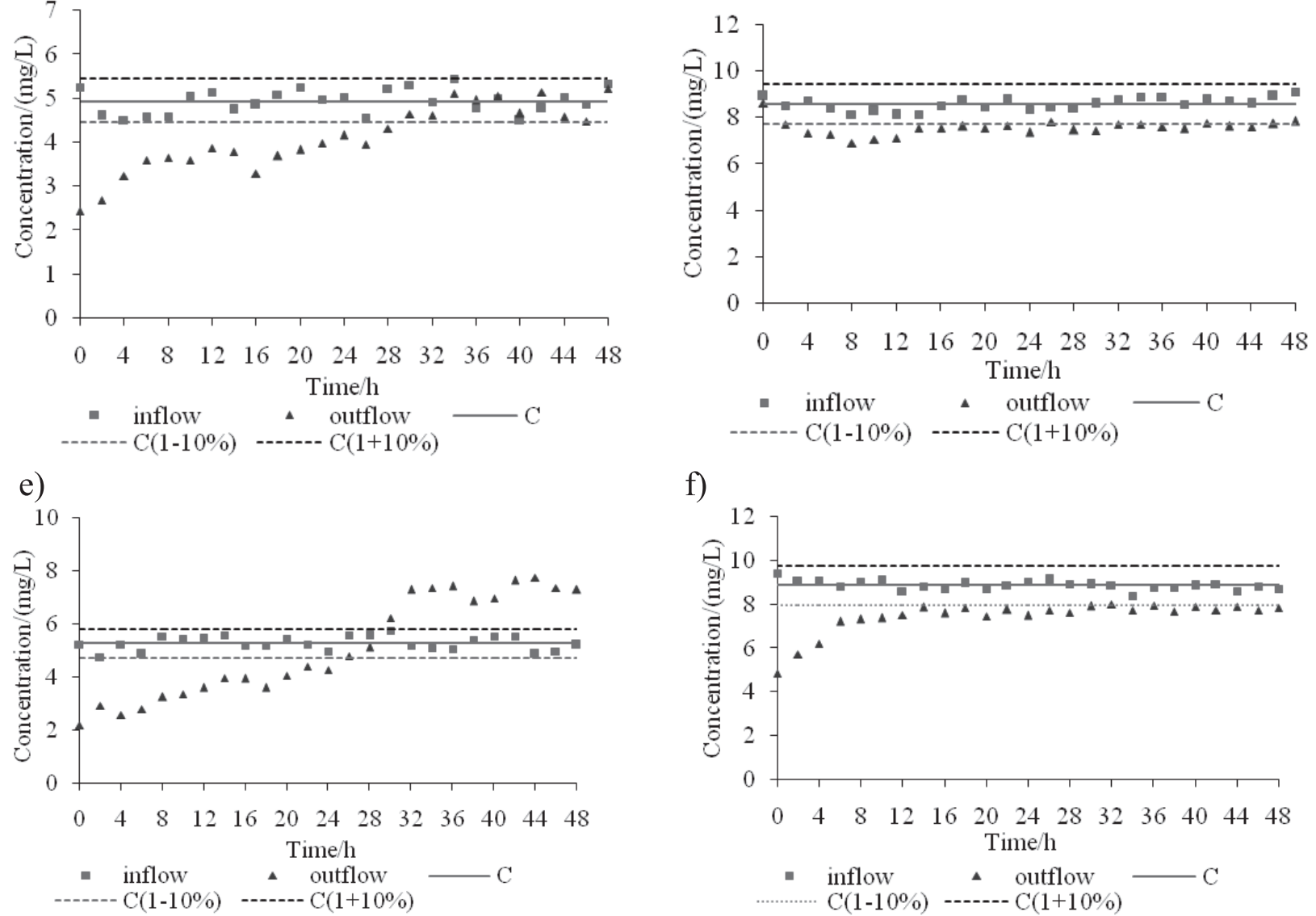

f)

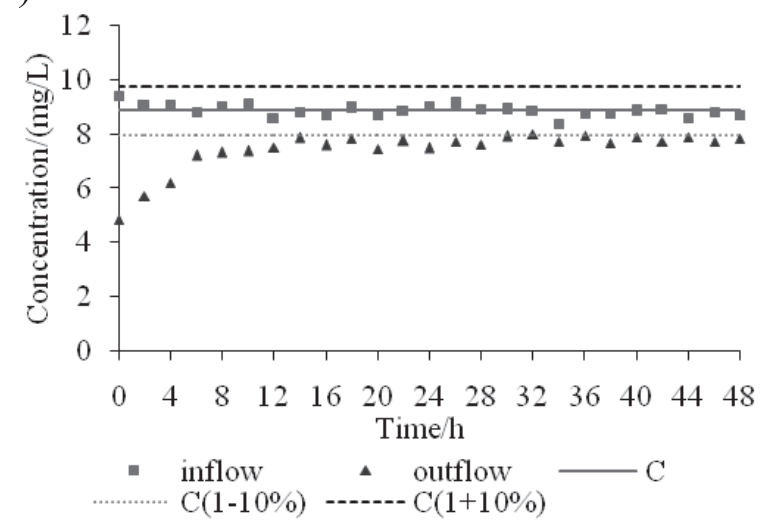

Fig. 4. Concentration change process in continuous operation. ' $\mathrm{C}$ ' refers to influent pollutant concentration: a) $\mathrm{NH}_{3}-\mathrm{N}$ at $7 \#$, b) $\mathrm{NO}_{3}-\mathrm{N}$ at $7 \#$, c) $\mathrm{NH}_{3}-\mathrm{N}$ at $9 \#$, d) $\mathrm{NO}_{3}-\mathrm{N}$ at $9 \#$, e) $\mathrm{NH}_{3}-\mathrm{N}$ at $10 \#$, f) $\mathrm{NO}_{3}-\mathrm{N}$ at $10 \#$. 
percentages of the accumulated pollutants, $\mathrm{NH}_{3}-\mathrm{N}$ and $\mathrm{NO}_{3}-\mathrm{N}$, in total inflow pollutant load of three bioretention tanks when they reached exhaustion point as follows: \#7, $77.39 \%$ and $76.02 \%$; $\# 9,59.93 \%$ and $61.94 \%$; and $\# 10$, $48.9 \%$ and $36.5 \%$ - demonstrating the relatively poor performance of planting soil.

The discharge ratio of the bioretention basin was 17:1, and its surface area was $1 \mathrm{~m}^{2}$. The rainfall volumes in $17 \mathrm{~m}^{2}$ catchment area of $7 \#, 9 \#$, and $10 \#$ bioretention basins were $0.52,0.34$, and 0.26 year of rainfall in Xi'an when $\mathrm{NH}_{3}-\mathrm{N}$ achieved exhaustion. The corresponding water volume reduction rates of the basins were $28.82 \%$, $31.84 \%$, and $34.84 \%$, respectively. Corresponding rainfall volumes for $\mathrm{NO}_{3}-\mathrm{N}$ were $0.30,0.15$, and 0.15 year of rainfall in $\mathrm{Xi}$ 'an, and water volume reduction rates were $44.28 \%, 34.84 \%$, and $34.84 \%$, respectively. O'Neill et al. [26] studied phosphorus adsorption though a $2.5 \mathrm{~cm}$ inner diameter mini-column, and inflow concentration of the dissolved phosphorus was $120 \mu \mathrm{g} / \mathrm{L}$. Media without WTR, hardwood bark, or leaf compost were evidently exhausted. The inflow volumes of the two unamended groups (BSM, bioretention soil media and LFBSM, low-fines bioretention soil media) of bioretention were 220 and $250 \mathrm{~mm}$ rainfall volume of the 20:1 catchment ratio when BSM achieved exhaustion, which is probably equal to 0.23 year of the rainfall in the District of Columbia. The accumulation rainfall volume increased several tens of times when special media was combined into the bioretention soil media to achieve exhaustion. In continuous operational test, $\mathrm{NH}_{3}-\mathrm{N}_{\text {and }} \mathrm{NO}_{3}-\mathrm{N}$ actual mean inflow concentrations were 5.1 and $8.5 \mathrm{mg} / \mathrm{L}$, respectively. The experimental result indicated that nitrogen pollutant can achieve adsorption exhausted points in a relatively short time under continuous operation fast adsorption, and the performance of $\mathrm{NO}_{3}-\mathrm{N}$ is more evident.

\section{PLS Modeling Analysis}

TN removal rate was the only dependent variable $y$ in the statistical analysis of TN removal for bioretention facilities. The independent variable $x$ included the inflow pollutant concentration, inflow hydraulic loading, antecedent dry time, submerged zone height, and media factor. All factors had two variables, except for antecedent

Table 5. Model samples of TN concentration removal rates and impact factors.

\begin{tabular}{|c|c|c|c|c|c|c|c|}
\hline $\begin{array}{c}\text { Test } \\
\text { number }\end{array}$ & GN & $\mathrm{IC}(\mathrm{mg} / \mathrm{L})$ & $\mathrm{IV}(\mathrm{L})$ & ADT (day) & $\mathrm{SD}(\mathrm{mm})$ & $\operatorname{PF}\left(10^{-3} \mathrm{~d} / \mathrm{m}\right)$ & $\mathrm{MV}(\%)$ \\
\hline \multirow{3}{*}{ Test 1} & $7 \#$ & 12.73 & 529.73 & 7 & 0 & 530.73 & 46.16 \\
\hline & 9\# & 12.73 & 532.14 & 7 & 0 & 157.79 & 31.37 \\
\hline & $10 \#$ & 12.73 & 520.69 & 7 & 0 & 264.23 & 19.79 \\
\hline \multirow{3}{*}{ Test 2} & $7 \#$ & 13.87 & 536.49 & 7 & 150 & 530.73 & 50.32 \\
\hline & 9\# & 13.87 & 535.11 & 7 & 150 & 157.79 & 40.88 \\
\hline & $10 \#$ & 13.87 & 532.53 & 7 & 150 & 264.23 & 34.17 \\
\hline \multirow{3}{*}{ Test 4} & $7 \#$ & 13.57 & 525.88 & 15 & 0 & 530.73 & 39.57 \\
\hline & 9\# & 13.57 & 539.16 & 15 & 0 & 157.79 & 15.40 \\
\hline & $10 \#$ & 13.57 & 525.43 & 15 & 0 & 264.23 & 11.79 \\
\hline \multirow{3}{*}{ Test 5} & $7 \#$ & 12.85 & 532.82 & 7 & 0 & 530.73 & 45.45 \\
\hline & 9\# & 12.85 & 525.21 & 7 & 0 & 157.79 & 28.17 \\
\hline & $10 \#$ & 12.85 & 515.11 & 7 & 0 & 264.23 & 17.82 \\
\hline \multirow{3}{*}{ Test 6} & $7 \#$ & 13.90 & 546.71 & 3 & 0 & 530.73 & 51.87 \\
\hline & 9\# & 13.90 & 533.03 & 3 & 0 & 157.79 & 45.25 \\
\hline & $10 \#$ & 13.90 & 524.76 & 3 & 0 & 264.23 & 19.06 \\
\hline \multirow{3}{*}{ Test 7} & $7 \#$ & 12.69 & 353.76 & 7 & 0 & 530.73 & 50.51 \\
\hline & 9\# & 12.69 & 361.49 & 7 & 0 & 157.79 & 33.57 \\
\hline & $10 \#$ & 12.69 & 359.63 & 7 & 0 & 264.23 & 19.62 \\
\hline \multirow{3}{*}{ Test 9} & $7 \#$ & 23.17 & 518.86 & 7 & 0 & 530.73 & 44.84 \\
\hline & 9\# & 23.17 & 517.71 & 7 & 0 & 157.79 & 24.13 \\
\hline & $10 \#$ & 23.17 & 503.54 & 7 & 0 & 264.23 & 19.90 \\
\hline
\end{tabular}

Note: GN is groove number; IC is inflow concentration of TN; IV is inflow volume; ADT is antecedent dry time; SD is submerged depth; PF is packing factor; MV is measured values of TN. 
Table 6. Test samples of measured and predicted TN removal rates and impact factors.

\begin{tabular}{|c|c|c|c|c|c|c|c|c|}
\hline Test number & GN & IC(mg/L) & IV(L) & ADT(day) & SD (mm) & PF $\left(10^{-3} \mathrm{~d} / \mathrm{m}\right)$ & PV $(\%)$ & MV $(\%)$ \\
\hline \multirow{3}{*}{ Test 3 } & $7 \#$ & 13.02 & 526.03 & 7 & 0 & 530.73 & 49.31 & 43.899 \\
\cline { 2 - 10 } & $9 \#$ & 13.02 & 531.52 & 7 & 0 & 157.79 & 28.88 & 24.111 \\
\cline { 2 - 10 } & $10 \#$ & 13.02 & 520.81 & 7 & 0 & 264.23 & 15.90 & 29.795 \\
\hline \multirow{3}{*}{ Test 8 } & $7 \#$ & 14.03 & 507.05 & 7 & 0 & 530.73 & 49.31 & 43.680 \\
\cline { 2 - 10 } & $9 \#$ & 14.03 & 525.44 & 7 & 0 & 157.79 & 29.58 & 23.840 \\
\cline { 2 - 10 } & $10 \#$ & 14.03 & 534.41 & 7 & 0 & 264.23 & 16.11 & 29.446 \\
\hline
\end{tabular}

Note: GN is groove number; IC is inflow concentration of TN; IV is inflow volume; ADT is antecedent dry time; SD is submerged depth; PF is packing factor; PV is predicted values of TN; MV is measured values of TN.

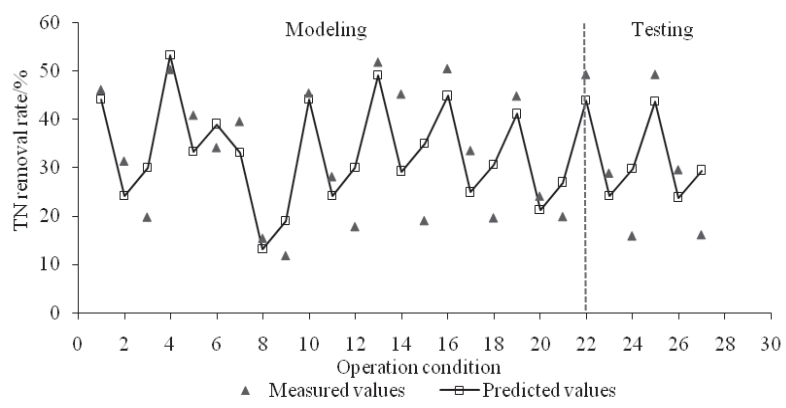

Fig. 5. Comparison of predicted and measured values.

dry time and media factor, which had three variables. Curve analysis showed a strong linear relationship between TN concentration and influencing factors. Thus, Equation (4) and the primitive variable Equation (5) in the PLS model were standardized as follows:

$$
\begin{gathered}
y^{*}=a_{1} x_{1}+a_{2} x_{2}+a_{3} x_{3}+a_{4} x_{4}+a_{5} x_{5} \\
\hat{y}=b_{0}+b_{1} x_{1}+b_{2} x_{2}+b_{3} x_{3}+b_{4} x_{4}+b_{5} x_{5}
\end{gathered}
$$

...where $y$ is the TN removal rate $(\%), x_{1}$ is the inflow $\mathrm{TN}$ concentration $(\mathrm{mg} / \mathrm{L}), x_{2}$ is inflow hydraulic loading (L), $x_{3}$ is the antecedent dry time (day), $x_{4}$ is the submerged zone height $(\mathrm{mm})$, and $x_{5}$ is the media factor (media adsorption capacity divided by the padding infiltration rate) $\left(10^{-3} \mathrm{~d} / \mathrm{m}\right)$.

Twenty-one groups of data from seven rainfall events were considered as modeling samples. Tests 3 and 8 were used in the model examination, and the modeling and examination samples are listed in Tables 5 and 6. The standardized variable Equation (6) is as follows:

$$
\begin{gathered}
y^{*}=-0.079 x_{1}-0.019 x_{2}-0.346 x_{3}+0.255 x_{4}+ \\
+0.647 x_{5}
\end{gathered}
$$

The primitive variable Equation (7) is as follows:

$$
\begin{gathered}
\hat{y}=31.056- \\
-0.292 x_{1}-0.004 x_{2}-1.340 x_{3}+ \\
+0.063 x_{4}+0.053 x_{5}
\end{gathered}
$$

The difference between simulated and measure values of TN removal was analyzed using PLS (Fig. 5). The regression line for the observed values showed better fitting with deterministic coefficient $R^{2}$ of 0.622 . The simulated and measured values were close (residuals within 16).

As shown in Fig. 6, The result from the PLS analysis between $\mathrm{TN}$ removal rate and influencing factors showed a)

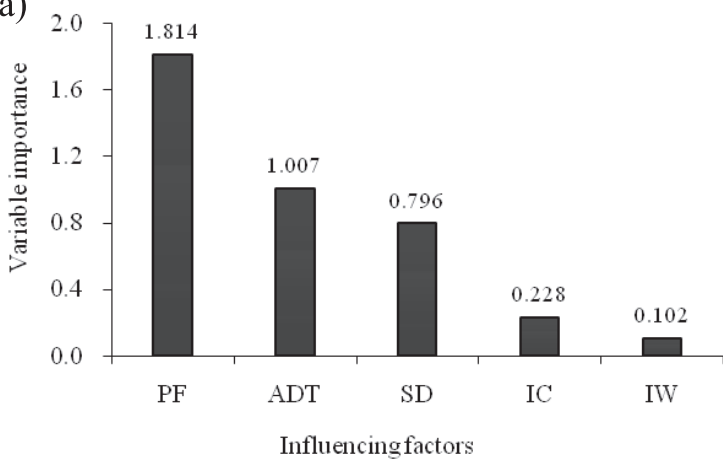

b)

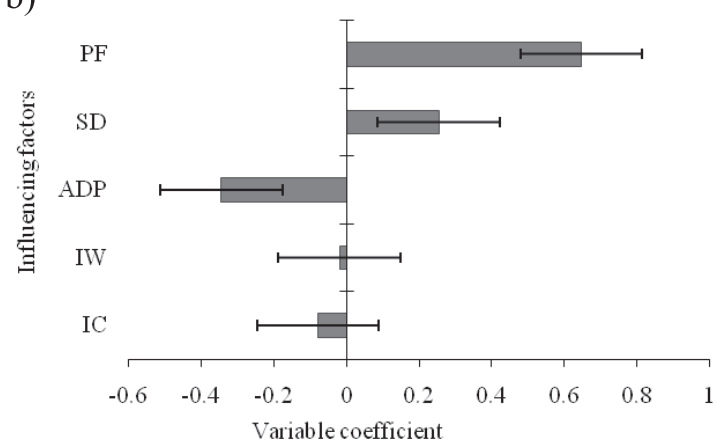

Fig. 6. a) Analysis of influencing factors; b) Correlation analysis of removal rate and influencing factors (PF, packing factor; ADT, antecedent dry time; SD, submerged depth; IC, inflow concentration; and IW, inflow water). 
that media factor was the most important influencing factor for TN removal in the bioretention facilities. The order of importance in other factors is as follows: antecedent dry time, submerged depth, inflow concentration, and inflow water volume. Five important factors were selected in the study. Antecedent dry time, inflow concentration, and inflow water volume were considered as the external influencing factors for bioretention ponds. Packing factor and submerged zone height were considered the internal influencing factors. Correlation analysis showed a positive relationship between $\mathrm{TN}$ removal and the media factor and submerged zone height. This result indicates that the higher the media factor and deeper the submerged zone, the greater $\mathrm{TN}$ removal will be. However, a negative relationship was found between $\mathrm{TN}$ removal and antecedent dry time, inflow concentration, and inflow hydraulic loading. TN removal rate was relatively worse with longer antecedent dry time, relatively high inflow concentration, and inflow hydraulic loading.

\section{Conclusions}

Intermittent and continuous running test results showed that the $7 \#$ bioretention tank had the highest pollutant load cut rate, and the trend of water pollutant concentration increased gradually with time. BFS as artificial packing layer (9\#) followed 7\#, but pure planting soil bioretention (10\#) showed the worst results. Pollutant concentration performances of $9 \#$ and $10 \#$ showed fluctuating tendencies, followed by gradual reduction. When $7 \#$, 9\#, and $10 \#$ reached their exhaustion points, the percentages of pollutant loads that accumulated in the media and the total inflow pollutant load followed the order of $7 \#>9 \#>10 \#$. The media is the most critical factor for the removal efficiency of nitrogen compared with antecedent dry time, submerged area height, inflow concentration, and inflow volume. A positive relationship was found between TN removal rate and packing factors and submerged area height. By contrast, a negative relationship was found between $\mathrm{TN}$ removal rate and antecedent dry time, submerged area height, inflow concentration, and inflow volume.

The microbial role in bioretention tanks should be strengthened in future studies, and the accumulated status and migration process of runoff pollutants in bioretention systems should be explored further. Pollutant migration should be studied over time using long-term test or simulation to evaluate the lifespan of bioretention.

\section{Acknowledgements}

This research was financially supported by the Natural Science Foundation of Shaanxi Province (No. 2015JZ013), and the National Natural Science Foundation of China (Nos. 51279158 and 51209168).

\section{References}

1. LI J.K., LI H.E., DONG W. Estimation of non-point source pollution characteristics and loading in Xi' an urban areas. J. Hydro. Eng., 31, 131, 2012 [In Chinese].

2. Ministry of Environmental Protection of the People's Republic of China. Report on the state of environment in China, 2015 [In Chinese].

3. DAVIS A.P., SHOKOUHIAN M., SHARMA H., MINAMI C. Water quality improvement through bioretention media: Nitrogen and phosphorus removal. Water Environment Research, 78, 284, 2006.

4. EGODAWATTA P., THOMAS E., GOONETILLEKE A. Mathematical interpretation of pollutant wash-off from urban road surfaces using simulated rainfall.Water Res., 41, 3025, 2007

5. MIGUNTANNA N.P., LIU A., EGODAWATTA P., GOONETILLEKE A. Characterising nutrients wash off for effective urban storm water treatment design. J. Environ. Manage, 120, 61, 2013.

6. TAYLOR G.D., FLETCHER T.D., WONG T. H.F., BREEN P.F., DUNCAN H.P. Nitrogen composition in urban runoffimplications for stormwater management. Water Res. 39 (10), 1982, 2005

7. LEFEVRE G.H., ASCE S.M., PAUS K.H., NATARAJAN P., GULLIVER J.S., ASCE F., NOVAK P.J., HOZALSKI R. M. Review of dissolved pollutants in urban storm water and their removal and fate in bioretention cells. J. Environ. Eng. 141, 04014050-1, 2015.

8. LI L.Q., DAVIS A.P. Urban stormwater runoff nitrogen composition and fate in bioretention systems. Environ Sci Technol, 48, 3403, 2014.

9. MANKAA B.N., HATHAWAYA J.M., TIRPAKA R.A., HE Q., HUNT W.F. Driving forces of effluent nutrient variability in field scale bioretention. Ecological Engineering. 94, 622, 2016.

10. BROWN R.A., HUNT W.F. Underdrain configuration to enhance bioretention exfiltration to reduce pollutant loads. J. Environ. Eng. 137 (11), 1082, 2011.

11. BRATIERES K., FLETCHER T.D., DELETIC A., ZINGER Y. Nutrient and sediment removal by storm water biofilters: A large-scale design optimization study. Water Res., 42 (14), 3930, 2008

12. WANG X.L., WANG J.E., GAN L.L., XING W., LIAO H. F., RUAN W.Q. Treatment of urban runoff pollutants by a multilayer biofiltration system. Environmental Science, 36, 2518, 2015 [In Chinese].

13. MA Z.Z. Survey of water pollution into the river in rural areas and experimental study on bioretention technology. Southeast University, Nanjing, 2014 [In Chinese].

14. ZINGER Y., BLECKEN G.T., FLETCHER T.D., VIKLANDERB M., DELETICA A. Optimising nitrogen removal in existing stormwater biofilters: Benefits and tradeoffs of a retrofitted saturated zone. Ecological Engineering. 51, 75, 2013.

15. EMILY G.I., FLETCHER T.D., COOK L.M., DELETICA A., HATTA B.E. Processes and drivers of nitrogen removal in stormwater biofiltration. Critical Reviews in Environmental Science and Technology, 44, 796, 2014.

16. LU J.S., CHEN Y., ZHENG Q., RUI D.U., WANG S.P., WANG J.P. Derivation of Rainstorm Intensity Formula in Xi'an City. China water \& waste water. 26, 82, 2010 [In Chinese]. 
17. YUAN H.L. Analysis of quality variation of rainwater in Xi'an. Xi'an Univ. of Arch.\&Tech. (Natural Science Edition), 43, 391, 2011 [In Chinese].

18. DONG W. Study on Non-point Source Pollution Characteristics and Control of Northwest City - Take Xi'an as an example. Xi' an Univ. of Tech. Xi'an, 2013 [In Chinese].

19. CEN G.P., SHEN J., FAN R.S. Research on Rainfall Pattern of Urban Design Storm. Advances in Water Science, 9, 41, 1998 [In Chinese].

20. State Environmental Protection Administration of China. Technical Specification for Soil Environmental Monitoring (HJ/T 166-2004). 2004.

21. HSIEH C.H., DAVIS A.P., NEEDELMAN B.A. Nitrogen removal from urban stormwater runoff through layered bioretention columns. Water Environ. Res. 79, 2404, 2007.

22. O'NEILL S.W., DAVIS A P. Water treatment residual as a bioretention amendment for phosphorus II: Long- Term Column. J. Environ. Eng., 138, 328, 2012.
23. MULLANE J.M., FLURY M., IQBAL H., FREEZE P.M., HINMAN C., COGGER C.G., SHI Z.Q. Intermittent rainstorms cause pulses of nitrogen, phosphorus, and copper in leachate from compost in bioretention systems. Science of the Total Environment, 537, 294, 2015.

24. LUCKE T., PETER W.B. The pollution removal and stormwater reduction performance of street-side bioretention basins after ten years in operation. Science of the Total Environment. 536, 784, 2015.

25. TANG S.C., LUO W., JIA Z.H., LI S., WU Y. An experimental study on $\mathrm{N}$ and $\mathrm{P}$ reductions in a rain garden and the influence of preferential flow. SHUILI XUEBAO. 46 (8), 943, 2015.

26. O'NEILL S.W., DAVIS A.P. Water treatment residual as a bioretention amendment for phosphorus.I: Evaluation Studies. J. Environ. Eng., 138, 318, 2012. 